DOI: https://doi.org/10.24127/ajpm.v10i2.3649

\title{
PROBLEM BASED LEARNING BERBANTU GOOGLE CALSSROOM TERHADAP KEMAMPUAN PEMAHAMAN KONSEP MATEMATIS
}

\author{
Sofri Rizka Amalia ${ }^{1 *}$, Dian Purwaningsih ${ }^{2}$, Wikan Budi Utami ${ }^{3}$ \\ ${ }^{1,2}$ Universitas Peradaban, Bumiayu, Indonesia \\ ${ }^{3}$ Universitas Pancasakti, Tegal, Indonesia \\ *Corresponding author. \\ E-mail: $\quad$ sofri.rizkia@gmail.com ${ }^{\left.{ }^{*}\right)}$ \\ dian.purwaningsih24@yahoo.com $^{2)}$ \\ wikan.piti@gmail.com $^{3)}$
}

Received 30 March 2021; Received in revised form 13 June 2021; Accepted 29 June 2021

\begin{abstract}
Abstrak
Penelitian ini bertujuan untuk mengetahui kemampuan pemahaman konsep matematis siswa yang diajarkan dengan model problem based learning berbantu google classroom lebih baik dari kemampuan pemahaman konsep matematis siswa yang yang diajar dengan whatsapp group. Penelitian ini merupakan penelitian eksperimen dengan desain postest only control design. Populasi dalam penelitian ini adalah siswa jurusan IPA SMA Negeri 5 Tegal yang terdiri dari 5 kelas. Sedangkan sampel yang digunakan dalam penelitian ini adalah X IPA 3 sejumlah 35 siswa sebagai kelas yang diajar PBL berbantu google classroom, dan X IPA 1 sebagai kelas yang diajar dengan whatsapp group sejumlah 35 siswa. Pengumpulan data dalam penelitian ini menggunakan tes dan dokumentasi. Teknik analisisi data dalam penelitian ini adalah uji indepentent $t$ test dengan bantuan SPSS. Hasil penelitian ini adalah kemampuan pemahaman konsep siswa yang diajarkan dengan model problem based learning berbantu google classroom lebih baik dari kemampuan pemahaman konsep matematis siswa yang yang diajar dengan whatsapp group.
\end{abstract}

Kata kunci: Kemampuan pemahaman konsep matematis; problem based learning berbantu google classroom; whatsapp group.

\begin{abstract}
This study aims to determine the understanding of students' mathematical concepts taught with the google class problem-based learning model is better than the ability of students to understand mathematical concepts taught by the WhatsApp group. This research is an experimental study with a posttest only control design. The population in this study were students majoring in science at SMA Negeri 5 Tegal which consisted of 5 classes. Whereas the sample used in this study was X IPA 3 with a total of 35 students as a class that was taught by PBL assisted by google classroom, and X IPA 1 as a class that was taught by whatsapp group of 35 students. Collecting data in research using tests and documentation. The data analysis technique in this study was the independent t test with the help of SPSS. The result of this research is that the understanding of the concept of students who are taught with the google class problem-based learning model is better than the ability to understand the mathematical concepts of students taught by the WhatsApp group.
\end{abstract}

Keywords: Mathematical concept understanding ability; google classroom assisted learning; whatsapp groups.

This is an open access article under the Creative Commons Attribution 4.0 International License

\section{PENDAHULUAN}

Indonesia mendapatkan skor matematika sebesar 370 pada programme for Internasional Student Assesment (PISA) tahun 2018. Sedangkan skor OECD sebesar 489 
(OECD, 2019). Skor Indonesia lebih rendah dari skor OECD. Oleh karena itu perlunya meningkatkan kemampuan matematis siswa.

Kemampuan matematis perlu dikembangkan dan dilatih di sekolah dengan baik. Kemampuan dalam memahami konsep merupakan kemampuan dasar yang harus di miliki oleh siswa supaya lebih mudah dalam mempelajari matematika tingkat lanjut (Septia et al., 2019).

Permasalahan menonjol yang dihadapi adalah kurangnya pemahaman konsep. Masih ada siswa yang hanya menghafal rumus tanpa mengetahui proses untuk mendapatkan rumus tersebut dan tidak mengerti maksudnya (Fariana, 2017). Permasalahan lain adalah siswa mengalami kesulitan dalam dalam menjelaskan kembali konsep serta memberikan contoh dan non contoh dari konsep sehingga mengakibatkan kesulitan dalam menerapkan konsep secara logis (Septia et al., 2019). Dapat disimpulkan bahwa kurangnya pemahaman konsep merupakan permasalahan yang mendasar yang terjadi dalam pembelajaran matematika.

Berdasarkan hasil wawancara guru SMA 5 Negeri Tegal menunjukkan bahwa sebagian siswa belum bisa mengungkapkan kembali materi yang telah diberikan guru. Siswa juga masih kurang tepat dalam menyebutkan mana yang contoh dan bukan contoh. Siswa mengerjakan soal tanpa membuat gambar/ grafik sesuai soal dan tidak mengubah soal yang berkaitan dengan kehidupan sehari-hari menjadi model matematika. Padahal dengan mengubah ke dalam model matematika dapat memudahkan siswa dalam menyelesaikan masalah.

Permasalahan tersebut terjadi saat awal terjadinya wabah covid-19. Pembelajaran yang biasanya menggu- nakan pembelajan tatap muka berubah menjadi pembelajaran jarak jauh. Siswa dan guru mengalami kebingungan dalam pembelajaran, khususnya mata pelajaran matematika. berbagai upaya dilakukan untuk meningkatkan kemampuan pemahaman konsep siswa.

Pemilihan model pembelajaran dan aplikasi yang dipakai merupakan salah satu solusi yang tepat. Model problem based learning (PBL) merupakan salah satu model yang dapat digunakan. Hal ini diperkuat oleh beberapa hasil penelitian. Penelitian Utomo, Wahyuni dan Hariyadi (2014) menyebutkan bahwa model PBL berpengaruh terhadap pemahaman konsep siswa. Penelitian lain menunjukkan bahwa median gain skor pemahaman konsep matematis siswa dengan model PBL lebih tinggi daripada median gain skor pemahaman konsep matematis siswa dengan pembelajaran konvensional (Septia et al., 2019). Sedangkan menurut penelitian Yanti, Asnawati, dan Wijaya (2019), peningkatan pemahaman konsep matematis siswa yang mengikuti model PBL lebih tinggi dibandingkan dengan peningkatan pemahaman konsep matematis siswa yang mengikuti model konvensional. Berdasarkan hasil beberapa penelitian dapat disimpulkan bahwa model PBL lebih baik dari pembelajaran konvensional.

Penerapan model PBL dipadukan dengan Google Classroom. Hasil penelitian menyebutkan bahwa efektivitas pengembangan E-modul pembelajaran berbasis masalah menggunakan Google Classroom efektif terhadap pembelajaran dan memiliki dampak yang besar (Putri \& Usmaedi, 2020). Penelitian lain menyebutkan penerapan pembelajaran problem based learning yang dipadukan dengan google classroom meningkatkan 
kemampuan pemahaman konsep (Rachmat, 2020). Penggunaan google classroom diharapkan akan memudahkan siswa dan guru berkomunikasi, selain itu guru dapat memberikan materi melalui link/ media lain dan latihan soal agar pembelajaran bermakna.

Kebaruan penelitian ini adalah penerapan model PBL yang dipadukan dengan Google Classroom. Pembelajaran yang mengguanakan PBL akan membuat siswa memahami dari permasalahan sehari hari. Hal ini dapat membuat pembelajaran lebih bermakna sehingga dapat meningkatkan kemampuan pemahaman konsep siswa. Pembelajaran PBL berbantuan Google Classroom dapat membantu siswa dalam mendapatkan materi secara online, melakukan diskusi, mendapatkan latihan soal sehingga lebih memahami materi di masa pandemi covid-19.

Berdasarkan uraian diatas, tujuan penelitian ini adalah untuk mengetahui kemampuan pemahaman konsep matematis siswa yang diajarkan dengan model problem based learning berbantu google classroom lebih baik dari kemampuan pemahaman konsep matematis siswa yang yang diajar dengan whatsapp group.

\section{METODE PENELITIAN}

Penelitian ini merupakan penelitian eksperimen dengan desain postest only control design (Ratminingsih, 2010). Penelitian dilakukan dengan menerapkan model PBL berbantu google classroom pada kelas eksperimen. Sedangkan pada kelas kontrol menerapkan pembelajaran dengan whatsapp group. Setelah dilakukan perlakukan,dilakukan postest untuk memperoleh kemampuan pemahaman konsep siswa.

Penelitian di lakukan di SMA Negeri 5 tegal. Populasi dalam penelitian ini adalah siswa jurusan IPA SMA Negeri 5 Tegal yang terdiri dari 5 kelas. Sedangkan sampel yang digunakan dalam penelitian ini adalah $\mathrm{X}$ IPA 3 sejumlah 35 siswa sebagai kelas yang diajar PBL berbantu google classroom, dan X IPA 1 sebagai kelas yang diajar dengan whatsapp group sejumlah 35 siswa.

Pengumpulan data dalam penelitian ini menggunakan tes. Tes digunakan untuk mendapatkan data kemampuan pemahaman konsep matematis siswa. Intrumen yang digunakan adalah lembar tes kemampuan pemahaman konsep yang terdiri dari 10 soal. Tes tersebut disesuaikan dengan indikator kemampuan pemahaman konsep (Septia et al., 2019).

Sebelum tes digunakan, dilkukan uji validitas soal product moment, uji reliabilitas Alfa Cronbach, daya pembeda dan tingkat kesukaran (Yusup, 2018). Teknik analisisi data dalam penelitian ini adalah uji indepentent $t$ test dengan bantuan SPSS.

\section{HASIL DAN PEMBAHASAN}

Penelitian dilakukan dengan menerapkan model PBL berbantu google classroom pada kelas X IPA 1 dan pembelajaran dengan whatsapp group pada kelas X IPA 3. Saat pembelajaran guru membuat materi di power point dan microsoft sway. Materi dan latihan soal di upload di google classroom. Pembelajaran di X IPA 3 dengan membuat whatsapp group. Materi yang diberikan menggunakan file buku siswa. Tugas diberikan di whatsapp group dan dikumpulkan secara pribadi melalu chat. Komunikasi dilakukan di whatsapp group.

Setelah pembelajaran materi vektor selesai, guru memberikan posttest untuk mendapatkan data kemampuan pemahaman konsep siswa. 
Sebelum soal posttest diberikan kepada siswa, terlebih dahulu dilakukan analisis uji coba soal test.

Analisis hasil uji coba tes kemampuan pemahaman konsep matematis siswa menunjukkan bahwa terdapat 9 soal valid, dan soal merupakan soal yang reliabel. Perhitungan tingkat kesukaran menghasilkan 2 soal dengan kriteria sukar, 7 soal dengan kriteria sedang, dan 1 soal dengan kriteria mudah. Sedangkan perhitungan daya pembeda menghasilkan 2 soal yang ditolak dan 8 soal yang diterima. Berdasarkan hasil analisis dapat disimpulkan bahwa dari 10 soal tes terdapat 7 soal yang dapat digunakan dalam penelitian.

Analisis data dalam penelitian ini menggunakan uji Independent Samples Test dengan bantuan SPSS. Sebelum melakukan uji tersebut dilakukan uji prasyarat yaitu uji homogenitas dan uji normalitas. Uji normaitas digunakan untuk mengetahui kedua kelas berdistribusi normal. Hipotesis uji normalitas adalah sebagai berikut.

$H_{0} \quad$ : Data berdistribusi normal

$H_{1} \quad$ : Data tidak berdtribusi normal Hasil uji normalitas dapat dilihat pada Tabel 4.

Tabel 4. Hasil tests of normality

\begin{tabular}{lrrr}
\hline & \multicolumn{3}{c}{ Shapiro-Wilk } \\
\cline { 2 - 4 } & Statistic & df & \multicolumn{1}{c}{ Sig. } \\
\hline PBL_GC &, 964 & 34 &, 320 \\
WA_G &, 947 & 34 &, 101 \\
\hline
\end{tabular}

Berdasarkan pada Tabel 4, diperoleh hasil yaitu nilai signifikan Shapiro Wilk kelas yang diajar dengan model PBL berbantu google classroom sebesar $0,320>0,05$. Terlihat 0,320 > 0,05 , maka Ho diterima artinya data berdistribusi normal. Sedangkan signifikan kelas yang diajarkan dengan whatsapp group sebesar 0,101. Terlihat bahwa 0,101 > 0,05, maka maka Ho diterima artinya data berdistribusi normal.

Kemudian setelah dilakukan uji normalitas, dilanjutkan dengan uji homogenitas. Hipotesis dari uji homogenitas, yaitu:

$H_{0}$ : Kelas sampel homogen

$H_{1}$ : Kelas sampel tidak homogen

Hasil uji homogenitas dapat dilihat pada Tabel 2.

Tabel 2. Hasil test of homogeneity of variances

\begin{tabular}{crrr}
\hline $\begin{array}{c}\text { Levene } \\
\text { Statistic }\end{array}$ & df $_{\mathbf{1}}$ & df $_{\mathbf{2}}$ & Sig. \\
\hline 2,589 & 1 & 66 &, 112 \\
\hline
\end{tabular}

Berdasarkan Tabel 5, nilai signifikan uji levene statistic sebesar 0,112 . Terlihat bahwa 0,112 >0,05, maka Ho di terima. Artinya data memiliki varian yang sama (homogen).

Setelah uji prasyarat terpenuhi, maka dilakukan uji independent $t$ test. Hipotesis yang digunakan adalahsebagai berikut.

$H_{0}: \mu_{1} \leq \mu_{2} \quad$ (kemampuan pemahaman konsep matematis siswa yang diajarkan dengan model problem based learning berbantu google classroom kurang dari sama dengan kemampuan pemahaman konsep matematis siswa yang yang diajar dengan whatsapp group)

$H_{1}: \mu_{1}>\mu_{2}$ (kemampuan pemahaman konsep matematis siswa yang diajarkan dengan model problem based learning berbantu google classroom lebih dari kemampuan pemahaman konsep matematis siswa yang yang diajar dengan whatsapp group)

Hasil dari uji independent t test dapat dilihat pada Tabel 3. 
DOI: https://doi.org/10.24127/ajpm.v10i2.3649

Tabel 3. Hasil independent samples test

\begin{tabular}{llccr}
\hline & \multicolumn{3}{c}{ t-test for Equality of Means } \\
\cline { 3 - 5 } & & $\mathbf{t}$ & df & Sig. (2-tailed) \\
\hline Model & Equal variances assumed & 3,044 & 66 &, 003 \\
& Equal variances not assumed & 3,044 & 65,045 &, 003 \\
\hline
\end{tabular}

Berdasarkan output hasil independent sampel test pada Tabel 3, dapat dilihat pada baris equal variance assumed diperoleh nilai $t=3,044$ dengan derajat kebebasan $(d f)=66$. Dengan taraf signifikan $5 \%$ diperoleh $t_{\text {tabel }}=t_{(66,0,05)}=1,667$. Terlihat jelas bahwa nilai $t_{\text {hitung }}>t_{\text {tabel }}$ atau $3,044>1,667$. Dengan demikian, $H_{0}$ ditolak, aartinya kemampuan pemahaman konsep matematis siswa yang diajarkan dengan model problem based learning berbantu google classroom lebih dari kemampuan pemahaman konsep matematis siswa yang yang diajar dengan whatsapp group.

Hasil uji tersebut sesuai dengan kenyataan di lapangan. Penerapan model PBL berbantu google classroom dilakukan dengan beberapa langkah pembelajaran yaitu orientasi siswa pada masalah, mengorganisasi siswa untuk belajar, membimbing pengalaman individu atau kelompok, mengembangkan dan menyajikan hasil karya, menganalisis dan mengevaluasi proses belajar. Pada tahap orientasi pada masalah, siswa diberikan permasalahan berkaitan dengan dunia nyata yang harus dipecahkan. Siswa dapat mengembangkan kemampuan pemahaman konsepnya dengan mencari informasi dan memilih solusi dari masalah yang tepat. Hal ini membuat siswa lebih memahami materi dan pembelajaran lebih bermakna. Setelah itu, siswa diberi kesempatan menyajikan hasil kerjanya di depan kelas secara dengan video. Siswa diberikan kesempatan untuk melakukan tanya jawab saat diskusi. Hal ini dapat membantu siswa yang masih belum memahami materi dan melihat sejauh mana kemampuan pemahaman konsep siswa. Pada tahap evaluasi, guru memberikan evaluasi terhadap hasil penyelesaian masalah yang dilakukan. Tahap ini membuat siswa tidak mengalami salah konsep karena guru memberikan arahan dan bimbingan untuk menyelesaikan masalah dengan tepat. Berdasarkan uraian diatas dapat disimpulkan bahwa Penerapan model PBL berbantu google classroom berpengaruh terhadap kemampuan pemahaman konsep.

Sedangkan penerapan pembelajaran dengan whatsapp group yaitu siswa diberi kesempatan mempelajari buku sesuai dengan materi. Kemudian siswa diberi kesempatan untuk mengerjakan soal latihan yang ada dibuku. Setelah menyelesaikannya, siswa dapat mengirim screenshot jawaban yang di whatsapp group. Guru mengevaluasi hasil jawaban siswa. Hal ini dapat membuat siswa mengembangkan kemampuan pemahaman mahasiswa. Akan tetapi, kemampuan yang terbentuk kurang maksimal. Hal ini disebabkan hanya mahasiswa yang aktif dan mampu mengerjakan soal saja yang lebih berkembang kemampuannya.

Kekurangan yang terjadi saat penerapan pembelajaran model PBL berbantu google classroom adalah pada tahap penyelesian masalah, guru tidak dapat secara langsung mengobservasi kemampuan siswa saat prosesnya karena dilaksanakan secara online. Sedangkan kekurangan yang terjadi saat pembelajaran dengan whatsapp group adalah materi yang diberikan belum tentu dipahami oelh siswa karena siswa 
DOI: https://doi.org/10.24127/ajpm.v10i2.3649

hanya diberikan kesempatan untuk membaca buku tanpa pemberian masalah yang berkaitan dengan materi. Selain itu, siswa yang pintar akan lebih aktif dan responsif dalam pembelajaran. Hal ini menyebabkan kemampuan pemahaman konsep hanya berkembang pada beberapa siswa saja. Berdasarkan uraian diatas, dapat disimpulkan bahwa kemampuan pemahaman konsep matematis siswa yang diajarkan dengan model problem based learning berbantu google classroom lebih dari kemampuan pemahaman konsep matematis siswa yang diajar dengan whatsapp group.

Hal ini sejalan dengan hasil penelitian Kertinus et al. menunjukkan bahwa terdapat pengaruh model pembelajaran problem based learning terhadap pemahaman konsep dan pemecahan masalah (2019). Penelitian lain menyebutkan bahwa, peningkatan pemahaman konsep matematis siswa yang mengikuti model PBL lebih tinggi dibandingkan dengan peningkatan pemahaman konsep matematis siswa yang mengikuti model konvensional (Yanti et al., 2019); (Septia et al., 2019). Selain itu, menurut Rohana (2020) pembelajaran daring saat ini menjadi media yang efektif untuk proses pembelajaran di semua jenjang. Ada beberapa model pembelajaran yang ditawarkan oleh para ahli di masa pandemic Covid-19 Model Daring, Model Luring, Model e-learning Daring, Project Based Learning, dan Blended Learning. Proses pembelajaran dapat berjalan dengan baik dengan adanya teknologi informasi diantaranya e-learning, google class, whatsapp, zoom serta media infromasi lainnya serta jaringan internet sehingga proses belajar mengajar dapat berjalan dengan baik meskipun ditengah pandemi virus corona covid-19 (Pakpahan \& Fitriani, 2020). Penelitian lain menyebutkan bahwa pembelajaran menggunakan model PBL dengan media google classroom berpengaruh signifikan terhadap aktivitas dan hasil belajar siswa (Yusuf \& Bektiarso, 2020). Selain itu, penggunaan google classroom dalam pembelajaran sehingga dapat meningkatkan pemahaman terhadap materi dan memotivasi siswa untuk memperoleh kualitas belajar dan hasil belajar yang lebih baik (Nurani et al., 2020).

Menurut Rachmat (Rachmat, 2020), penerapan pembelajaran problem based learning yang dipadukan dengan Google Classroom meningkatkan kemampuan pemahaman konsep. Penggunaan google classroom dapat memudahkan pengumpulan tugas secara online tepat waktu sehingga mengurangi pengumpulan tugas yang terlambat. Hal ini dapat menjadi perubahan guru dan siswa dari cara tradisional menjadi berbasis e-leaarning untuk meningkatkan kualitas pembelajaran secara keseluruhan (Bhat et al., 2018).

Implikasi dalam penelitian ini adalah model PBL dapat diterapkan untuk meningkatkan kemampuan pemahaman konsep. Pada saat pandemi covid-19 penerapan PBL dapat dipadukan dengan google classroom dan whatsapp group. Keduanya cukup baik dalam meningkatkan kemampuan pemahaman konsep. Akan tetapi, perpaduan antara model PBL dan google classroom lebih baik dari penggunaan whatsapp group.

\section{KESIMPULAN DAN SARAN}

Berdasarkan hasil penelitian dapat disimpulkan bahwa kemampuan pemahaman konsep matematis siswa yang diajarkan dengan model problem based learning berbantu google classroom lebih baik dari pada siswa yang diajar dengan whatsapp group. 
DOI: https://doi.org/10.24127/ajpm.v10i2.3649

Saran dalam penelitian ini adalah model PBL berbantu google classroom dapat digunakan untuk mengembangkan kemampuan pemahaman konsep siswa. Selain itu, sebaiknya penggunaan whatsapp group dipadukan dengan model pembelajaran yang tepat. Pemberian materi saat whatsapp group dan google classroom dapat berupa video yang dibuat guru atau link video yang dapat menghubungkan siswa dengan Youtube.

\section{DAFTAR PUSTAKA}

Bhat, S., Raju, R., Bikramjit, A., \& Souza, R. D. (2018). Leveraging E-Learning through Google Classroom: A Usability Study. Journal OfEngineering Education Transformations, 31(3), 1-7.

Fariana, M. (2017). Implementasi Model Problem Based Learning untuk Meningkatkan Pemahaman Konsep. Journal of Medives, 1(1), 25-33.

Kertinus, R., Darma, Y., \& Wahyudi. (2019). Pengaruh Problem Based Learning terhadap Pemahaman Konsep dan Pemecahan Masalah dalam Materi Hukum Archimedes. Edukasi, 17(2), 135-144.

Nurani, N. I., Uswatun, D. A., Maula, L. H., \& Sukabumi, U. M. (2020). Analisis Proses Pembelajaran Matematika Berbasis Daring Menggunakan Aplikasi Google Classroom pada Masa Pandemi Covid-19. Jurnal PGSD, 6(1), 4956.

OECD. (2019). PISA 2018 Results (Volume I): What Students Know and Can Do, PISA: Vol. I. OECD Publishing.

https://doi.org/https://doi.org/10.17 87/5f07c754-en
Pakpahan, R., \& Fitriani, Y. (2020). Analisa Pemanfaatan Teknologi Informasi dalam Pembelajaran Jarak Jauh di Tengah Pandemi Virus Corona Covid-19. JISAMAR, 4(2), 30-36.

Putri, hengraini eka, \& Usmaedi. (2020). The Development of E Modules Problem Based Learning Using Google Classroom for Basic Electricity and Electronics. Cyberspace, 4(2), 84-93.

Rachmat, M. (2020). Problem Based Learning Combined With Google Classroom on Kinetic Gas In Grade XI Science 5 Cibinong 3 Highschool. Wahana Jurnal of Action Research (2020), 2(2), 1-9.

Ratminingsih, N. made. (2010). Experimental Research in Second Language. PRASI, 6(11), 30-40.

Rohana, S. (2020). Model Pembelajaran Daring Pasca Pandemi Covid-19. At-Ta'dib: Jurnal Ilmiah Prodi Pendidikan Agama Islam, 12(2), 192.

https://doi.org/10.47498/tadib.v12i 02.441

Septia, E., Asih, B., Sutiarso, S., \& Wijaya, A. P. (2019). Pengaruh Model Problem Based Learning Terhadap Pemahaman Konsep Matematis Siswa. Jurnal Pendidikan Matematika Unila, 7(2), 146-157.

Utomo, T., Wahyuni, D., Hariyadi, S., Studi, P., Biologi, P., Keguruan, F., \& Unej, U. J. (2014). Pengaruh Model Pembelajaran Berbasis Masalah ( Problem Based Learning ) Terhadap Pemahaman Konsep dan Kemampuan Berpikir Kreatif Siswa ( Siswa Kelas VIII Semester Gasal SMPN 1 Sumbermalang Kabupaten Situbondo Tahun Ajaran 2012 / 2013 ) ( The Effect of Pro. 7, 5-9. 
DOI: https://doi.org/10.24127/ajpm.v10i2.3649

Yanti, R. A., Asnawati, R., \& Wijaya, A. P. (2019). Pengaruh Model Problem Based Learning terhadap Pemahaman Konsep Matematis Siswa. Jurnal Pendidikan Matematika, 7(4), 464-476.

Yusuf, N. R., \& Bektiarso, S. (2020). Pengaruh Model Pbl Dengan Media Google Classroom Terhadap. 6(November), 230-235.

Yusup, F. (2018). Uji Validitas dan Reliabilitas Instrumen Penelitian Kuantitatif. Jurnal Tarbiyah: Jurnal Ilmiah Kependidikan, 7(1), 17-23.

https://doi.org/10.18592/tarbiyah.v $7 \mathrm{i} 1.2100$ 